RESEARCH ARTICLE

\title{
Pre-harvest herbicide application reduces the Italian ryegrass seed viability
}

\author{
Joanei Cechin ${ }^{1 *}$, Alcimar Mazon ${ }^{1}$, Silvio Thiago de Oliveira Raphaelli ${ }^{1}$, Dirceu Agostinetto ${ }^{1}$ and \\ Leandro Vargas ${ }^{2}$
}

\author{
1 Universidade Federal de Pelotas (UFPel), Pelotas-RS, Brasil. \\ ${ }^{2}$ Empresa Brasileira de Pesquisa Agropecuária (Embrapa Trigo), Passo \\ Fundo-RS, Brasil. \\ *Author for correspondence: joaneicechin@yahoo.com.br
}

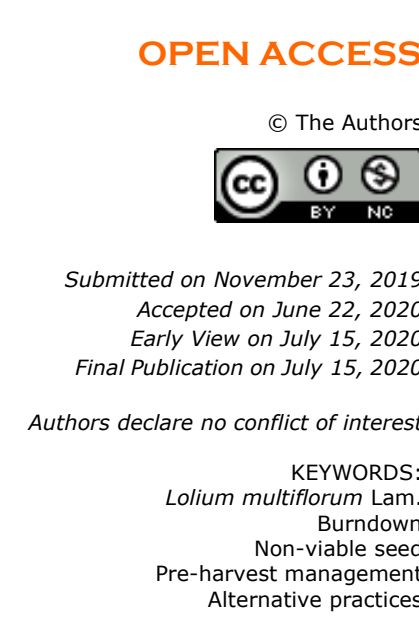

\section{ABSTRACT}

Italian ryegrass (Lolium multiflorum Lam.) is a troublesome weed found in temperate agricultural fields, wherein the future infestations depend on the soil seed bank. The aim of this research was to evaluate Italian ryegrass seed viability subjected to herbicide application in different phenological stages of development. Experiments were carried out in a completely randomized experimental design with four repetitions. Paraquat, ammonium-glufosinate, iodosulfuron-methyl and clethodim herbicides were applied in three development stages (prespike, anthesis, and grain filling) and compared to the control. The effects were evaluated by percentage of control at seven, 14, and 28 days after application (DAA), seeds per plant, 1000 seeds weight, and percentage of germination, abnormal seedlings, dead seeds, viable and non-viable dormant seeds. Control was greater than $97 \%$ at $28 \mathrm{DAA}$, with a decrease of more $90 \%$ for seed per plant, and strong reduction of 1000 seeds weight for the herbicides applied up to the anthesis stage. At the grain filling stage, clethodim reduced seed production by $18 \%$ and 1000 -seeds weight by $36 \%$ compared to the control. Ammonium-glufosinate and paraquat herbicides applied up to the anthesis stage reduced seed viability by more than $98 \%$. Overall, herbicide application reduces seed production, seed weight and viability, especially when applied before the grain filling stage.

\section{Highlighted Conclusions}

1. Herbicide application up to the anthesis developmental stages reduces seed production, 1000 seeds weight, and seed viability.

2. Paraquat was the best herbicide to reduce seed production per plant, 1000 -seeds weight and, viability of Italian ryegrass seeds, regardless of development stages.

3. Reducing future infestations of Italian ryegrass in cropping systems depends on herbicide application before the grain filling.

\section{INTRODUCTION}

Italian ryegrass (Lolium multiflorum Lam.) is a winter forage plant found in Southern Brazilian agricultural fields, widely used as animal pasture or as cover crops for no-tillage systems (Vargas and Roman 2005). However, this weed in wheat and barley crops can cause damage due to the effects of competition for limited and essential resources for development, causing economic damage and reducing yield potential (Agostinetto et al. 2008). Furthermore, the increase of Italian ryegrass populations with glyphosate-resistance in several fields occurred after high selection pressure by the repeated application of 5-enolpyruvilshikimate-3-phosphate synthase (EPSPS) inhibiting herbicides, reducing the chemical management options for control (Roman et al. 2004). Additionally, the high number of seeds per plant, early dehiscence, and easy dispersion due to seed shedding before wheat harvest, restores seed inputs into the soil bank and ensures future infestations (Norris 2007, Fernández-Moreno et al. 2017).

The adoption of chemical control and other management practices are strategies that can prevent the evolution of resistance and reduce its negative effects on crops, especially in fields with elevated number of resistant populations (Burgos et al. 2013). Efficient methods of weed control should increase seedling mortality, affect seed germination and plant development promoting the reduction of seed production and cause the exhaustion of the 
soil seed bank (Shaner and Beckie 2014, Chauhan et al. 2006). Thus, herbicides are considered important tools for integrated weed management due to the greater efficacy and lower costs compared to the physical and mechanical methods, reducing seed inputs and replenishment into the soil seed bank (Norsworthy et al. 2012). The inhibition of physiological processes caused by herbicides can affect seed formation, resulting in lower physiologic quality (Campos et al. 2012). For example, paraquat and glyphosate application before the complete wheat seed formation can cause lower germination and reduce the vigor (Perboni et al. 2018). In contrast, non-viable seeds production in Italian ryegrass after herbicide application depends on the plant phenological stages to provide higher effects on physiological quality.

Approaches on seed damage in Italian ryegrass caused by herbicides applied at pre-harvest are essential to evaluate the potential for reducing seed replenishment into the soil seed bank, preventing future weed infestations, and helping farmers by allowing the continuous use of production areas. The aim of this research was to evaluate Italian ryegrass seed viability subjected to herbicide application in different phenological stages of development.

\section{MATERIAL AND METHODS}

Experiment was carried out in a greenhouse during September-December of 2018, using the completely randomized experimental design with four repetitions. Plants were placed in plastic pots (unit experimental) with $2 \mathrm{~L}$ of volumetric capacity, containing soil+GerminPlant ${ }^{\circledR}$ substrate at 2:1 proportion. The soil was classified as Endoaquult (Soil Survey Staff 2014), in which the soil chemical analysis showed: $\mathrm{pH}=5.6, C T \mathrm{C}_{\mathrm{pH}}=7.2 \mathrm{cmolc}^{-3}$, organic matter $=1.5 \%$, clay $=16 \%, \mathrm{Ca}^{2+}=4.1 \mathrm{cmolc} \mathrm{dm}^{-3}, \mathrm{Mg}^{2+}=1.1 \mathrm{cmolc} \mathrm{dm}^{-3}, \mathrm{Al}=1.8 \mathrm{cmolc} \mathrm{dm}^{-3}, \mathrm{P}=6.5 \mathrm{mg} \mathrm{dm}^{-3}$, and $\mathrm{K}^{+}=0.15 \mathrm{cmol}_{\mathrm{c}} \mathrm{dm}^{-3}$. The fertilization was performed previously of the soil and substrate mixture, in accordance with the recommendations for forage crops (SBCS 2016).

Paraquat at a rate of $400 \mathrm{~g}$ ai. ha-1, ammonium-glufosinate at a rate of $400 \mathrm{~g}$ ai. ha-1, iodosulfuron-methyl at a rate of $5 \mathrm{~g}$ ai. ha-1, and clethodim herbicide at a rate of $120 \mathrm{~g}$ ai. ha-1 were applied in three different phenological stages (pre-spike, anthesis, and grain filling), according to the phenological scale adapted for winter cereals and weed (Lancashire et al. 1991), and compared with the control without herbicide. Herbicide applications were performed with a $\mathrm{CO}_{2}$ backpack sprayer, using Teejet TT 110.02 nozzles at a spraying volume of $120 \mathrm{I} \mathrm{ha}^{-1}$. The meteorological conditions found during the applications were $23.4,22.1$ and $24.5^{\circ} \mathrm{C}$ for temperature; 65,68 and $60 \%$ for relative air humidity, and $1.6,1.2$ and $1.1 \mathrm{~km} \mathrm{~h}^{-1}$ for wind speed, respectively, in each stage. The variables measured were control of Italian ryegrass, seed per plant, and 1000-seeds weight. The control was evaluated at seven, 14 and 28 days after application (DAA), using the percentage scale, which the zero and 100 values refer to the absence and complete death of the plants, respectively (Frans and Crowley 1986). Seed number was obtained by individual count from seven tillers plant ${ }^{-1}$ to compare the effects, with visualization of full seeds in a diaphanoscope of light. After harvest, the seeds were stored at $10^{\circ} \mathrm{C}$ for two months in kraft paper bags to perform the germination test.

For the seed viability, the analyzes were carried out in a seed laboratory using the completely randomized experimental design with four repetitions. A sampling from each treatment was performed, and 50 seeds were placed in each transparent boxes $(11.5 \times 11.5 \times 3.5 \mathrm{~cm})$, containing two sheets blotter paper, previously moistened with distilled water in an amount to 2.5 -fold the paper weight. The boxes were put in a chamber of Biochemical Oxygen Demand (BOD) for 14 days at alternating temperature $20 / 30{ }^{\circ} \mathrm{C}$ in dark/light, and $8 \mathrm{~h}$ of photoperiod, according to the Brazilian Rules for Seed Testing (Brasil 2009). Seed viability was evaluated at 14 days after starts the germination testing, based on the germination percentage, abnormal seedlings, dead seeds, percentage of dormant viable and non-viable seeds. The non-germinated seeds were analyzed in a $1 \%$ tetrazolium solution after longitudinally cut of embryo and imbibition at $30^{\circ} \mathrm{C}$ of temperature for $6 \mathrm{~h}$, with check-in in a stereo microscope (Brasil 2009).

The data were submitted to analysis of variance $(p<0.05)$, and the means of treatments compared by the Duncan's test $(p<0.05)$, whereas herbicide effects were compared with the control without herbicide by Scheffé test $(p<0.05)$.

\section{RESULTS AND DISCUSSION}

Our results demonstrated significant effects for the control, seed per plant, 1000-seeds weight, germination percentage, dead seeds, and viable and non-viable seed for herbicides applied in different phenological stages, except for abnormal seedlings with significant effects only for herbicide. Italian ryegrass control was greater for paraquat and ammonium-glufosinate herbicides, regardless of the phenological stage and with levels greater than $80 \%$ at seven days after application (Table 1 ). 
Table 1. Control (\%) at seven, 14 and 28 days after application (DAA) of paraquat, ammoniumglufosinate, iodosulfuron-methyl and clethodim for seed inviabilization of Italian ryegrass in different phenological stages.

\begin{tabular}{|c|c|c|c|c|}
\hline \multirow{2}{*}{ Herbicides } & \multirow{2}{*}{$\begin{array}{c}\text { Rate } \\
\left(\mathrm{g} \text { ai. ha }{ }^{-1}\right)\end{array}$} & \multicolumn{3}{|c|}{ Control 7 DAA } \\
\hline & & Pre-spike & Anthesis & Grain filling \\
\hline Paraquat & 200 & $84 \mathrm{Aa}$ & $82 \mathrm{Aa}$ & $80 \mathrm{Aa}$ \\
\hline Ammonium-glufosinate & 400 & $82 \mathrm{Aa}$ & $81 \mathrm{Aa}$ & $82 \mathrm{Aa}$ \\
\hline lodosulfuron-methyl & 5 & $44 \mathrm{Ca}$ & $42 \mathrm{Ca}$ & $45 \mathrm{Ba}$ \\
\hline Clethodim & 120 & $55 \mathrm{Ba}$ & $51 \mathrm{Ba}$ & $52 \mathrm{Ba}$ \\
\hline Control without herbicide & -- & $0.0 \mathrm{D}^{\mathrm{ns}}$ & $0.0 \mathrm{D}$ & $0.0 \mathrm{C}$ \\
\hline CV (\%) & & & 4.33 & \\
\hline \multirow{2}{*}{ Herbicides } & Rate & \multicolumn{3}{|c|}{ Control 14 DAA } \\
\hline & $\left(g\right.$ ai. ha $\left.^{-1}\right)$ & Pre-spike & Anthesis & Grain filling \\
\hline Paraquat & 200 & $99 \mathrm{Aa}$ & $98 \mathrm{Aa}$ & $99 \mathrm{Aa}$ \\
\hline Ammonium-glufosinate & 400 & $93 \mathrm{Ba}$ & $95 \mathrm{Aa}$ & $95 \mathrm{Aa}$ \\
\hline lodosulfuron-methyl & 5 & $83 \mathrm{Ca}$ & $82 \mathrm{Ba}$ & $80 \mathrm{Ba}$ \\
\hline Clethodim & 120 & $91 \mathrm{Ba}$ & $89 \mathrm{Ba}$ & $90 \mathrm{Ba}$ \\
\hline Control without herbicide & -- & $0.0 \mathrm{D}^{\mathrm{ns}}$ & $0.0 \mathrm{C}$ & $0.0 \mathrm{C}$ \\
\hline CV (\%) & & & 3.52 & \\
\hline \multirow{2}{*}{ Herbicides } & Rate & \multicolumn{3}{|c|}{ Control 28 DAA } \\
\hline & $\left(g\right.$ ai. $\left.h^{-1}\right)$ & Pre-spike & Anthesis & Grain filling \\
\hline Paraquat & 200 & $100 \mathrm{Aa}$ & $100 \mathrm{Aa}$ & $100 \mathrm{Aa}$ \\
\hline Ammonium-glufosinate & 400 & $100 \mathrm{Aa}$ & $100 \mathrm{Aa}$ & $99 \mathrm{Aa}$ \\
\hline lodosulfuron-methyl & 5 & $96 \mathrm{Ba}$ & $97 \mathrm{Ba}$ & $97 \mathrm{Ba}$ \\
\hline Clethodim & 120 & $99 \mathrm{Aa}$ & $99 \mathrm{Aa}$ & $99 \mathrm{Aa}$ \\
\hline Control without herbicide & -- & $0.0 \mathrm{C}^{\mathrm{ns}}$ & $0.0 \mathrm{C}$ & $0.0 \mathrm{C}$ \\
\hline CV (\%) & & & 2.55 & \\
\hline
\end{tabular}

For iodosulfuron-methyl and clethodim herbicides, the control was 40 and $25 \%$ lower than other herbicides. Similar results were found for iodosulfuron-methyl and clethodim herbicides applied at the pre-spike, anthesis and grain filling, in which the control was lower compared to the paraquat or ammonium-glufosinate (Table 1). In plants, paraquat have faster action due to changes promoted on electron transport on photosystem I during photosynthesis, resulting in hydrogen peroxide formation, which is important for lipid peroxidation and cell damage (Senseman 2007). Lower control levels found at 14 DAA for iodosulfuron-methyl and clethodim can occur due to a slower mode of action compared to paraquat and reduced translocation in more developed plants, in which the injury symptoms are visible from 7 to 14 days after application (Senseman 2007, Campos et al. 2012). Control levels greater than $96 \%$ were obtained for all herbicides at 28 DAA, with reduced effects for iodosulfuron-methyl applied at the grain filling stage (Table 1). Similar results were found for the iodosulfuron-methyl application at the flowering stage, which the control was 13\% lower than paraquat (Pereira et al. 2017).

Herbicides caused strong reduction on the seed number produced plant ${ }^{-1}$, especially for applications in the prespike stage, causing full reduction in the seed production compared to the control (Figure 1A). Paraquat and ammonium-glufosinate applied up to the anthesis stage were more efficient to reduce seed production compared to the control without herbicide, whereas iodosulfuron-methyl and clethodim reduced by 90 and $92 \%$ the seed number produced plant ${ }^{-1}$, respectively.

Late herbicide application increased Italian ryegrass seed production compared to early stages, although paraquat applied at grain filling reduced seed production by $81 \%$, compared to the control, whereas ammoniumglufosinate, iodosulfuron-methyl, and clethodim herbicides reduced seed production by 51,36 and $15 \%$, respectively (Figure 1A). Similar effects occurred in rigid ryegrass (L. rigidum Gaudin), with lower efficiency in reducing seed production (Steadman et al. 2005). In Spanish agricultural fields, the reduction of rigid ryegrass seed production with herbicides can reduce up to $45 \%$ the soil seed bank in the long-term (Gonzalez-Andujar and Fernandez-Quintanilla 2004). Thus, chemical control for failure management should be performed up to anthesis stages to prevent viable seed production. Herbicide application up to anthesis affected the 1000-seeds weight, with values $86 \%$ lower than the control without herbicide, in which the 1000 seeds weight was of 2.8 grams (Figure 1B). Clethodim applied at the grain filling stage reduced the 1000 -seeds weight, with values $35 \%$ lower than the control. Additionally, paraquat and ammonium-glufosinate had greater efficiency to reduce seed weight during grain filling (Figure 1B). Herbicide burndown in wheat pre-harvest reduced seed weight and hectoliter mass, affecting the seedling establishment (Krenchinski et al. 2017). However, seed weight reduction depends on the phenological stage, with lower effects for herbicide application after the grain filling (Perboni et al. 2018). 

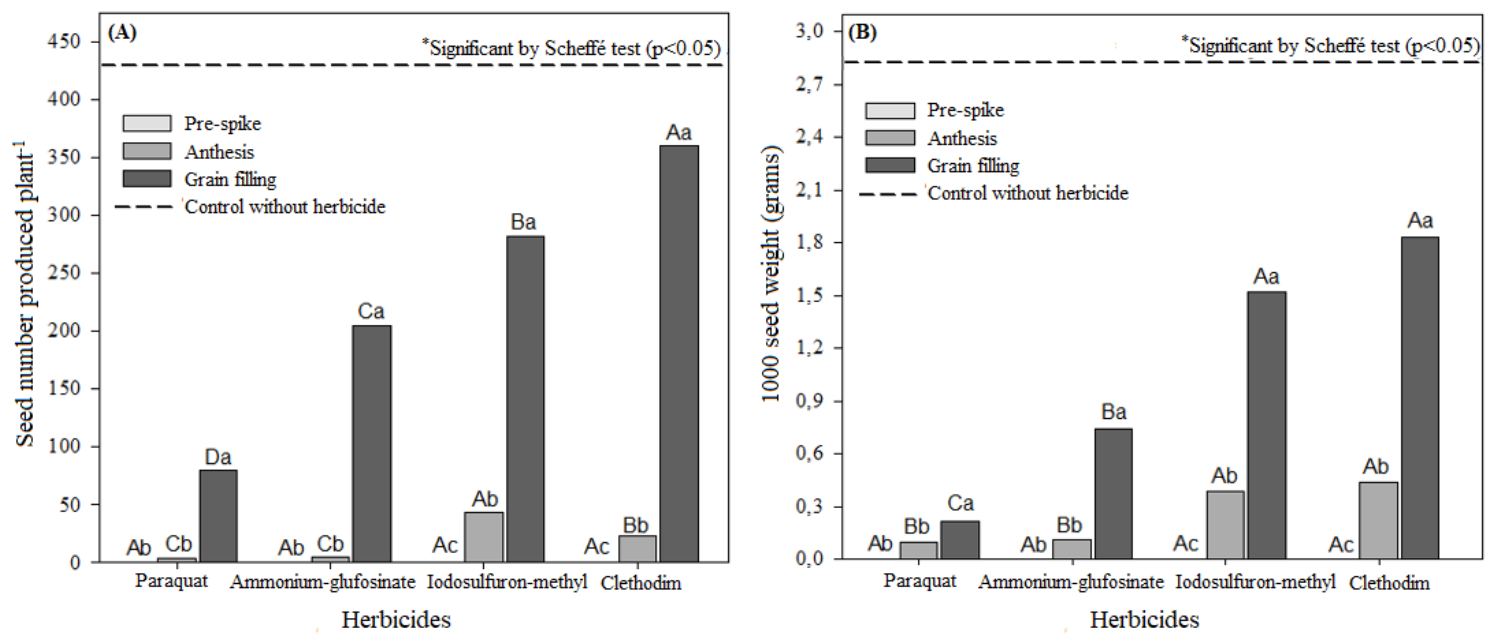

Figure 1. Seed production and 1000 seed weight after paraquat, ammonium-glufosinate, iodosulfuron-methyl and clethodim application for seed inviabilization of Italian ryegrass in different phenological stages. Same lowercase letters compare the herbicide effects in the different stages, and uppercase letters compare the herbicides in each stage by Duncan's test $(p<0.05)$. "significant effect for control without herbicide by Scheffé test $(p<0.05)$.

Lower germination percentages were found for all herbicides applied, regardless of the phenological stages evaluated compared to the control, in which the germination was of $89 \%$ (Table 2). Herbicides application at prespike and anthesis stages caused strong reduction in germination (decreases greater than 98\%), except for iodosulfuron-methyl applied after the anthesis stage, with the germination of $21 \%$ (Table 2). In wheat plants, recent studies have been reporting the negative effects on seed germination after paraquat and glyphosate application due to the oxidative damage of membranes caused when herbicides are applied in the pre-harvest (Bellé et al. 2014, Perboni et al. 2018). The increase of dead seeds occurred for all herbicides applied in the pre-spike and anthesis stages, with decreases greater than $98 \%$, except for iodosulfuron-methyl applied at anthesis in which dead seeds were only $76 \%$ (Table 2). Furthermore, late herbicide application reduced the percentage of dead seeds, especially for iodosulfuron-methyl applied at grain filling, with $66 \%$ of dead seeds. Herbicides are chemical substances that modify several physiological processes, affecting grain filling and seed quality, especially for applications performed before seed maturity (Jaskulski and Jaskulska 2014). Wheat burndown with ammoniumglufosinate, clethodim or paraquat can reduce the initial growth of seedlings due to the incomplete formation and lower seed weight (Krenchinski et al. 2017).

Viable and non-viable dormant seeds did not differ for herbicides applied at pre-spike and anthesis compared to the control (Table 2). However, the increase of viable dormant seeds was found for the application of iodosulfuron-methyl, with values of $5 \%$ for the application at grain filling stage (Table 2). For non-viable dormant seeds there were no differences due to herbicide application, with greater values obtained for iodosulfuron-methyl application at grain filling (Table 2). Higher weed seed dormancy can cause longer longevity in the soil seed bank and allow population fluctuations due to slow dormancy release, especially under unfavorable environmental conditions (Neé et al. 2017). Furthermore, limited seed reserves reduce viability and increase the deterioration rate through microbiota predation, whereas environmental changes of temperature and soil moisture can affect gas exchange and reduce seed viability on the long-term (Vivian et al. 2008; Agostinetto et al. 2018).

The percentage of abnormal seedlings did not differ from the control without herbicide, regardless of the phenological stage (Table 3). Abnormal seedlings are characterized by the incomplete structural formation of the seedling, resulting in plants with low vigor and lower competitive ability in cropping systems (Barth Neto et al. 2014). For weeds, the exploration of resources from the environment and field occupancy rely on seeds with high initial vigor and faster seedling emergence compared to the crop, important factors for growth and space occupancy (Vila-Aiub et al. 2015, Keshtkar et al. 2019).

Our investigation on non-germinated seeds also included the occurrence of seeds without embryo in the Italian ryegrass plants subjected to herbicide application, especially when applied at grain filling (Figure 2). Seed embryo absence precludes germination and prevent the growth of new plants, reducing weed dispersion and population density on the long-term (Neé et al. 2017). For Italian ryegrass, the adoption of management strategies that reduce seed inputs into the soil seed bank should be considered the major tool to reduce infestations, especially considering that seed viability is short, in this specie, for seeds present next to the soil surface (Cechin et al. 2021).

In general, herbicides applied in pre-harvest can be used to reduce seed viability and contribute for the management of Italian ryegrass resistant-populations, reducing the soil seed bank and future infestations. 
Table 2. Percentage of germination, dead seeds, viable and non-viable seeds after paraquat, ammonium-glufosinate, iodosulfuron-methyl and clethodim application for seed inviabilization of Italian ryegrass in different phenological stages.

\begin{tabular}{|c|c|c|c|c|}
\hline \multirow{2}{*}{ Herbicides } & \multirow{2}{*}{$\begin{array}{c}\text { Rate } \\
\left(\mathrm{g} \text { ai. } \mathrm{ha}^{-1}\right)\end{array}$} & \multicolumn{3}{|c|}{ Germination (\%) } \\
\hline & & Pre-spike & Anthesis & Grain filling \\
\hline Paraquat & 200 & $0.0 \mathrm{~B}^{\mathrm{ns}}$ & $0.0 \mathrm{C}$ & $0.0 \mathrm{D}$ \\
\hline Ammonium-glufosinate & 400 & $0.0 \mathrm{Bb}$ & $0.0 \mathrm{Cb}$ & $17 \mathrm{Ba}$ \\
\hline lodosulfuron-methyl & 5 & $0.0 \mathrm{Bb}$ & $21 \mathrm{Ba}$ & $22 \mathrm{Ba}$ \\
\hline Clethodim & 120 & $0.0 \mathrm{Bb}$ & $1.0 \mathrm{Cb}$ & $8.0 \mathrm{Ca}$ \\
\hline Control without herbicide & - & \multicolumn{3}{|c|}{ - } \\
\hline CV (\%) & & \multicolumn{3}{|c|}{11.90} \\
\hline \multirow{2}{*}{ Herbicides } & Rate & \multicolumn{3}{|c|}{ Dead seeds (\%) } \\
\hline & $\left(\mathrm{g}\right.$ ai. ha $\left.{ }^{-1}\right)$ & Pre-spike & Anthesis & Grain filling \\
\hline Paraquat & 200 & $100 \mathrm{Aa}$ & $100 \mathrm{Aa}$ & $95 \mathrm{Aa}$ \\
\hline Ammonium-glufosinate & 400 & $100 \mathrm{Aa}$ & $99 \mathrm{Aa}$ & $78 \mathrm{Bb}$ \\
\hline lodosulfuron-methyl & 5 & $99 \mathrm{Aa}$ & $76 \mathrm{Bb}$ & $66 \mathrm{Cc}$ \\
\hline Clethodim & 120 & $100 \mathrm{Aa}$ & $98 \mathrm{Aa}$ & $85 \mathrm{Bb}$ \\
\hline Control without herbicide & -- & \multicolumn{3}{|c|}{ - } \\
\hline CV (\%) & & & 15.64 & \\
\hline \multirow{2}{*}{ Herbicides } & Rate & \multicolumn{3}{|c|}{ Viable seeds (\%) } \\
\hline & (g ai. ha ${ }^{-1}$ ) & Pre-spike & Anthesis & Grain filling \\
\hline Paraquat & 200 & $0.0 \mathrm{Aa}$ & $0.0 \mathrm{Aa}$ & $2.0 \mathrm{Ba}$ \\
\hline Ammonium-glufosinate & 400 & $0.0 \mathrm{Aa}$ & $0.0 \mathrm{Aa}$ & $1.0 \mathrm{Ba}$ \\
\hline lodosulfuron-methyl & 5 & $0.0 \mathrm{Ab}$ & $1.0 \mathrm{Ab}$ & $5.0 \mathrm{Aa}$ \\
\hline Clethodim & 120 & $0.0 \mathrm{Aa}$ & $0.0 \mathrm{Aa}$ & $2.0 \mathrm{Ba}$ \\
\hline Control without herbicide & -- & & $1.0^{(\mathrm{ns})}$ & \\
\hline CV (\%) & & & 10.81 & \\
\hline \multirow{2}{*}{ Herbicides } & Rate & \multicolumn{3}{|c|}{ Non-viable seeds (\%) } \\
\hline & $\left(\mathrm{g}\right.$ ai. $\left.\mathrm{ha}^{-1}\right)$ & Pre-spike & Anthesis & Grain filling \\
\hline Paraquat & 200 & $0.0 \mathrm{Aa}$ & $0.0 \mathrm{Aa}$ & $3.0 \mathrm{Aa}$ \\
\hline Ammonium-glufosinate & 400 & $0.0 \mathrm{Aa}$ & $1.0 \mathrm{Aa}$ & $4.0 \mathrm{Aa}$ \\
\hline lodosulfuron-methyl & 5 & $0.0 \mathrm{Ab}$ & $1.0 \mathrm{Ab}$ & $6.0 \mathrm{Aa}$ \\
\hline Clethodim & 120 & $0.0 \mathrm{Ab}$ & $1.0 \mathrm{Ab}$ & $5.0 \mathrm{Aa}$ \\
\hline Control without herbicide & -- & \multicolumn{3}{|c|}{ - $1.0^{(\mathrm{ns})}$} \\
\hline CV (\%) & & & 8.31 & \\
\hline
\end{tabular}

${ }^{*}$ Means followed by the same uppercase letter (column) and lowercase letter (line) do not differ by Duncan's test ( $\left.p<0.05\right)$. ${ }^{\text {ns }}=$ not significant $(p<0.05)$. ${ }^{(1)}$ Favorable effect to control without herbicide compared to the herbicides applied by Scheffé test $(p \leq 0.05)$. ${ }^{(n)}=$ not significant by Scheffé test $(p<0.05)$.

Table 3. Abnormal seedlings of Italian ryegrass after paraquat, ammonium-glufosinate, iodosulfuron-methyl and clethodim application for seed inviabilization.

\begin{tabular}{|c|c|c|}
\hline \multirow{2}{*}{ Herbicides } & \multirow{2}{*}{$\begin{array}{l}\text { Rate } \\
\text { (g ai. ha-1) }\end{array}$} & \multirow{2}{*}{$\begin{array}{l}\text { Abnormal seedlings (\%) } \\
\text { Phenological stages }\end{array}$} \\
\hline & & \\
\hline Paraquat & 200 & $0.0 \mathrm{~A}$ \\
\hline Ammonium-glufosinate & 400 & $0.0 \mathrm{~A}$ \\
\hline lodosulfuron-methyl & 5 & $1.0 \mathrm{~A}$ \\
\hline Clethodim & 120 & $0.0 \mathrm{~A}$ \\
\hline Control without herbicide & -- & $1.0 \mathrm{~A}$ \\
\hline CV (\%) & & 8.21 \\
\hline
\end{tabular}

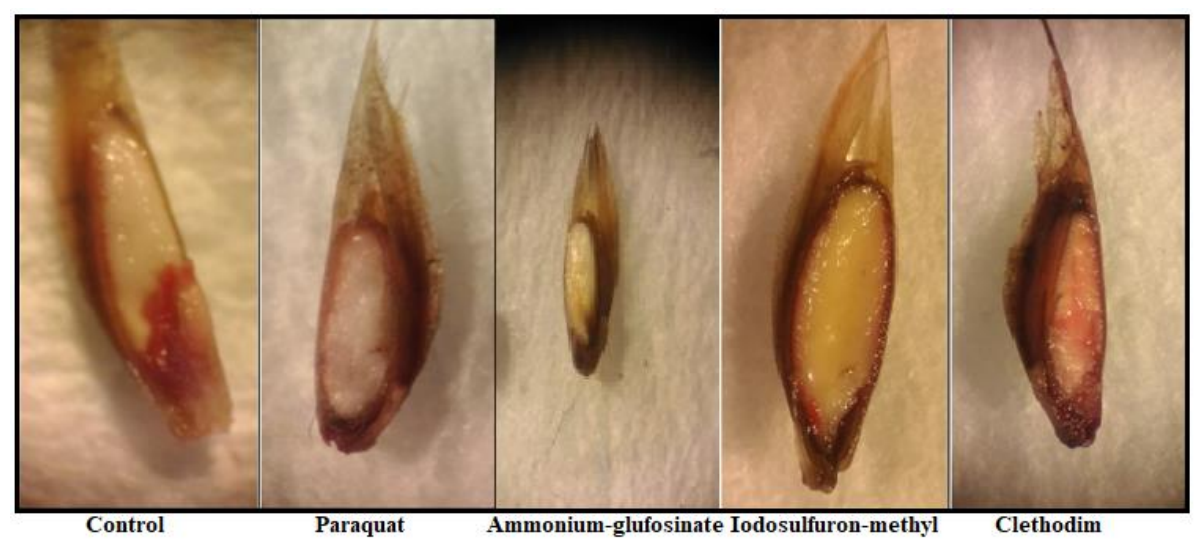

Figure 2. Effect of herbicides on Italian ryegrass seeds after application in the grain filling, demonstrating the absence of embryo. 


\section{Acknowledgements}

The first author thanks the Federal University of Pelotas, and the financial support by Coordenação de Aperfeiçoamento de Pessoal de Nível Superior (CAPES), Brazil - Finance code 001. Thanks also to the Embrapa/Bayer Project.

\section{References}

Agostinetto D et al. 2008. Período crítico de competição de plantas daninhas com a cultura do trigo. Planta Daninha 26: 271-278.

Agostinetto $D$ et al. 2018. Germination, viability and longevity of horseweed (Conyza spp.) seeds as a function of temperature and evaluation periods. Ciência Rural 48:e20170687.

Barth Neto A et al. 2014. Italian ryegrass establishment by self-seeding in integrated crop-livestock systems: Effects of grazing management and crop rotation strategies. European Journal of Agronomy 53:67-73.

Bellé $C$ et al. 2014. Yield and quality of wheat seeds as a function of desiccation stages and herbicides. Journal of Seed Science 36:63-70.

Brasil - Ministério da Agricultura, Pecuária e Abastecimento. 2009. Regras para análise de sementes. 395p.

Burgos NR et al. 2013. Review: Confirmation of resistance to herbicides and evaluation of resistance levels. Weed Science 26: 151-155.

Campos CF et al. 2012. Efeito de herbicidas na dessecação e germinação de sementes remanescentes de Lolium multiflorum L. Semina: Ciências Agrárias 33:2067-2074.

Chauhan BS et al. 2006. Influence of environmental factors on seed germination and seedling emergence of rigid ryegrass (Lolium rigidum). Weed Science 54: 1004-1012.

Cechin J et al. 2021. Burial depths favor Italian ryegrass persistence in the soil seed bank. Scientia Agricola.78:e20190078.

Fernández-Moreno PT et al. 2017. Differential resistance mechanisms to glyphosate result in fitness cost for Lolium perenne and $L$. multiflorum. Fronteirs in Plant Science 8: 1796.

Frans R and Crowley H. 1986. Experimental design and techniques for measuring and analyzing plant responses to weed control practices. In: Southern Weed Science Society. Research Methods in Weed Science. 3ed., pp.29-45.

Gonzalez-Andujar JL and Fernandez-Quintanilla C 2004. Modelling the population dynamics of annual ryegrass (Lolium rigidum) under various weed management systems. Crop Protection 23:723-729.

Jaskulski D and Jaskulska I 2014. The effect of pre-harvest glyphosate application on grain quality and volunteer winter wheat. Romanian Agricultural Research 31:283-289.

Keshtkar E et al. 2019. Assessing fitness costs from a herbicide-resistance management perspective: A review and insight. Weed Science 66:112.

Krenchinski FH et al. 2017. Yield and physiological quality of wheat seeds after desiccation with different herbicides. Journal of Seed Science 39:254-261.

Lancashire PD 1991. A uniform decimal code for growth stages of crops and weeds. Annals of Applied Biology 119:561-601.

Neé G et al. 2017. The release of dormancy, a wake-up call for seeds to germinate. Current Opinion in Plant Biology 35:8-14.

Norris RF 2007. Weed fecundity: Current status and future needs. Crop Protection 26:182-188.

Norsworthy JK et al. 2012. Reducing the risks of herbicide resistance: Best management practices and recommendations. Weed Science 60:31-62.

Perboni LT et al. 2018. Yield, germination and herbicide residue in seeds of preharvest desiccated wheat. Journal of Seed Science 40:304-312.

Pereira LV et al. 2017. Chemical control of Lolium multiflorum: effect of biotype and time of spraying. Revista de Ciências Agroveterinárias 16: 338-341.

Roman ES et al. 2004. Resistência de azevém (Lolium multiflorum) ao herbicida glyphosate. Planta Daninha 22:301-306.

SBCS - Sociedade Brasileira de Ciência do solo - Núcleo Regional Sul. 2016. Manual de adubação e calagem para os Estados do Rio Grande do Sul e Santa Catarina. 2ed. Santa Maria: Palotti. 375p.

Senseman SA. 2007. (Ed.). Herbicide handbook. 9ed. Lawrence: Weed Science Society of America. 458p.

Shaner DL and Beckie HJ 2014. The future for weed control and technology. Pest Management Science 70:1329-1339.

Soil Survey Staff. 2014. Keys to Soil Taxonomy by Soil Survey Staff Twelfth Edition. U.S. Department of Agriculture, Natural Resources Conservation Service, Washington, D.C., USA. 362p

Steadman KJ et al. 2005. Late-season non-selective herbicide application reduces Lolium rigidum seed number, seed viability, and seedling fitness. Australian Journal of Agricultural Research 57:133-141.

Vargas $L$ and Roman ES 2005. Seletividade e eficiência de herbicidas em cereais de inverno. Revista Brasileira de Herbicidas 4:1-10.

Vila-Aiub MM et al. 2015. Experimental methods for estimation of plant fitness costs associated with herbicide-resistance genes. Weed Science 63:203-217.

Vivian R et al. 2008. Efeito da luz e da temperatura na germinação de Alternathera tenella, Conyza bonariensis e Digitaria ciliaris. Planta Daninha 26:507-513. 